\title{
Evaluation on the Quality of Bangkok Tap Water with Other Drinking Purpose Water
}

\author{
A. Kordach*, C. Chardwattananon*, K. Wongin*, B. Chayaput* and N. Wongpat** \\ *Water Supply Section, Water Surveillance Division, Water Quality Department, Metropolitan Waterworks \\ Authority, 400 Prachacheun Road, Tungsonghong, Laksi, Bangkok 10210, Thailand \\ (Email: Auttapol.k@mwa.co.th) \\ **Director of Water Quality Department, Metropolitan Waterworks Authority, 400 Prachacheun Road, \\ Tungsonghong, Laksi, Bangkok 10210, Thailand \\ (Email: Nisapas@yahoo.com)
}

\begin{abstract}
The concern of drinking purposed water quality in Bangkok, Nonthaburi, and Samutprakarn provinces has been a problem for over fifteen years. Metropolitan Water Works Authority (MWA) of Thailand is fully responsible for providing water supply to the mentioned areas. The objective of Drinkable Tap Water Project is to make people realize in quality of tap water. Communities, school, government agencies, hotels, hospitals, department stores, and other organizations are participating in this project. MWA have collected at least 3 samples of water from the corresponding places and the samples have to meet the World Health Organization (WHO) guidelines level. This study is to evaluate water quality of tap water, storage water, filtered water, and filtered water dispenser. The water samples from 2,354 attending places are collected and analyzed. From October 2011 to September 2016, MWA analyzed 32,711 samples. The analyzed water parameters are free residual chlorine, appearance color, turbidity, $\mathrm{pH}$, conductivity, total dissolved solids (TDS), and pathogenic bacteria; E.coli. The results indicated that a number of tap water samples had the highest number compliance with WHO guidelines levels at $98.40 \%$. The filtered water, filtered water dispenser, and storage water were received $96.71 \%, 95.63 \%$, and $90.88 \%$, respectively. However, the several samples fail to pass WHO guideline level because they were contaminated by E.coli. The result is that tap water has the highest score among other sources probably because tap water has chlorine for disinfection and always is monitored by professional team round-the-clock services compared to the other water sources with less maintenance or cleaning. Also, water quality reports are continuously sent to customers by mail addresses. Tap water quality data are shown on MWA websites and Facebook. All these steps of work should enhance the confidence of tap water quality.
\end{abstract}

Keywords

Tap water; water quality; water supply; Metropolitan Water Works Authority (MWA); drinking water quality

\section{INTRODUCTION}

Metropolitan Waterworks Authority (MWA) is a State Enterprise, which has a major responsibility for tap water production in Bangkok, Nonthaburi, and Samut Prakarn Provinces in Thailand. Service areas cover 2,358-kilometer square and they are divided into 18 branches. MWA has four Water Treatment Plants and ten pumping stations. The production capacity is about 5.9 million cubic meters per day. The Chao Phraya River and Mae Klong River are water resources. Integrated water quality monitoring is managed for water resources and tap water quality. Bio monitoring and online raw water monitoring are used for raw water sources. Moreover, generally, the water samples are analyzed with Laboratories certified by ISO/IEC 17025 every month. In the crisis, the water is closely monitored with water treatment process by certified ISO 9001:2015, ISO 14001:2015 and HACCP. Furthermore, tap water is monitored, analyzed, and quality controlled by our scientists round-the-clock. (MWA Annual Report 2016) During the flooding crisis of Bangkok, although, MWA tap water had confidently complied with WHO guidelines level 2011 (Kitkaew, et.al, 2013), customers have lost trust on drinking water supply so one of the strategies is building trust by conducting a project "Drinkable Tap Water Project." Building up confidence for the customers is the key factor, the activities composed of 1) in-house water quality check, 2) 
maintaining water quality in storage tanks consultancy, 3) filter container or install correct pumps on communities, government agencies, educational institutions, hotels, hospitals, and private enterprises. Water quality for participating organizations which comply to WHO guidelines for drinking will be certified, and water quality will be continually mornitored at least once a year.

Table 1. Recommended minimum sample numbers for faecal indicator testing in distribution systems* of MWA referenced by WHO guidelines.

Type of water supply Total number of samples per year and population

\begin{tabular}{ll}
\hline $\begin{array}{l}\text { Point sources } \\
\text { Piped supplies }\end{array}$ & Progressive sampling of all sources over 3-to 5-years cycles (maximum) \\
$<5000$ & 12 \\
$5000-100000$ & 12 per 5000 population \\
$>100000-500000$ & 12 per 10000 population plus an additional 120 samples \\
$>500000$ & 12 per 50000 population plus an additional 600 samples \\
\hline
\end{tabular}

* Parameters such as chlorine, turbidity and $\mathrm{pH}$ should be tested more frequently as part of operational and verification monitoring.

In distribution systems, we also have plans and goals in water quality monitoring comply with WHO guidelines. As shown in Table 1, recommended minimum sample numbers for faecal indicator testing is 12 per 50,000 plus an additional 600 samples in the case of population is more than 500,000. (WHO 2011) MWA has clients about 10 million population in our services area (Annual Report 2016) so we have sampling plan in distribution systems about 3,000 samples per year. The number of samples collected from tap water pipes in distribution systems at customers' places cover all our services area; 18 branches, are shown in Fig.1. The distribution of collected sample is determined by the density of population in each service areas to analyze physical, chemical, and biological parameters.

Table 2. Annual list of analyzed MWA Tap water quality parameters

\begin{tabular}{|c|c|c|c|}
\hline Order & Water Quality & Parameters & Frequency \\
\hline 1 & Physical & Color, odor, turbidity & Everyday \\
\hline 2 & Chemical & $\begin{array}{l}\text { Free residual chlorine, iron, conductivity, total } \\
\text { dissolve solid }\end{array}$ & everyday \\
\hline & & Insight chemical 40 parameters & Once/month \\
\hline 3 & Bacteria & E.coli & Everyday \\
\hline 4 & Heavy metal & $\begin{array}{l}\text { Lead, chromium, cadmium, mercury, copper, zinc, } \\
\text { arsenic }\end{array}$ & Once/month \\
\hline 5 & Carcinogen & $\begin{array}{l}\text { Total organic carbon (TOC), Trihalomethane } \\
\text { (THMs) }\end{array}$ & Once/month \\
\hline 6 & Agricultural toxin & Organochlorine, organophosphate & Twice/year \\
\hline 7 & $\begin{array}{l}\text { Pathogenic } \\
\text { bacteria }\end{array}$ & $\begin{array}{l}\text { Vibrio Cholerae serotype o:1, Vibrio Cholerae } \\
\text { serotype non o: } 1 \text {, Samonella sp., Shigella sp., } \\
\text { Staphylococcus aureus, Clostridium perfringens }\end{array}$ & $\begin{array}{l}\text { Three times } \\
\text { /year }\end{array}$ \\
\hline 8 & Protozoa & $\begin{array}{l}\text { Cryptosporidium spp., Giardia spp., Cyclospora } \\
\text { spp. }\end{array}$ & Once/year \\
\hline 9 & Virus & Rotavirus, poliovirus, Hepatitis virus, Norovirus & Once/year \\
\hline 10 & Radioactive & Beta and alpha & Twice/year \\
\hline 11 & Microcystin & MC-LR, MC-YR, MC-RR & 4 times/years \\
\hline 12 & Phenol & Phenol & 4 times/years \\
\hline 13 & Cyanine & Cyanine & 4 times/years \\
\hline
\end{tabular}


Moreover, we plan to monitor water quality monitoring in toxic parameters, which cause deleterious effects to health; such as heavy metal, pesticide, agricultural toxin, carcinogen (trihalomethane), radioactive, and pathogenic bacteria, as shown in Table 2.

This study is to assure that tap water quality produced under responsibility of MWA, conforms to WHO guidelines for drinking water quality and does not differ from the other drinking water purpose. Many researchers found that tap water and bottled water had quite the same water quality. (Kornprabha et al. 2005, Marie Eliza Z. S. et al 2008, and Rosa et al 2011) In addition, this research disseminate tap water quality data to users in order to build their trust on MWA tap water quality and realize the importance of frequently cleaning water storage as well as related equipment in their places. The finding can resume the users' confidence in tap water consumption.

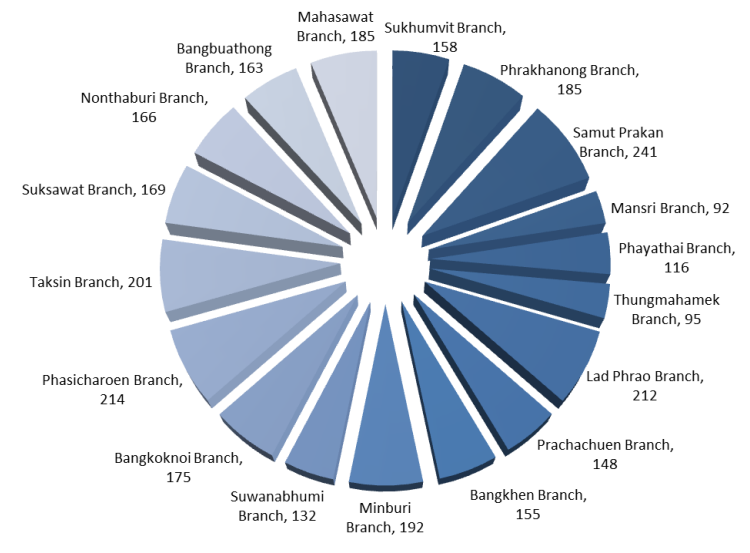

Fig. 1 Scheme of total water samples shown by number of sample per branches per years

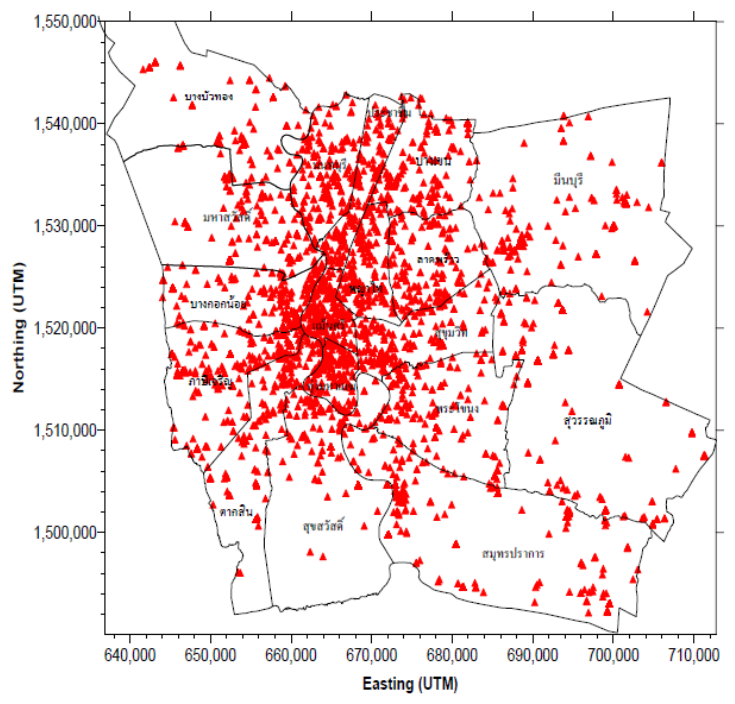

Fig.2 Observation data map of annual water sampling points 


\section{MATERIAL AND METHODS}

Water samples from participating in Drinkable Tap Water Project amount 2,354 places were collected during October 2011 to September 2016. The samples were collected from tap water pipes in distribution systems, storage tanks, filter tanks, filter dispensers, for at least three samples each places. The samples were analyzed in seven parameters; free residual chlorine (analyzed in the sampling points), appearance color, turbidity, $\mathrm{pH}$, conductivity, total dissolve solid (TDS), and E.coli. The analytical methods are shown in Table 3. The samples were collected in appropriate containers. Polyethylene plastic bottles $(250 \mathrm{ml})$ were used for physical and chemical parameters. For bacteria parameter, we used volume $120 \mathrm{ml}$ glasses, which had Sodiumthiosulfate $\left(\mathrm{Na}_{2} \mathrm{~S}_{2} \mathrm{O}_{3}\right)$ $3 \%$ amount of $0.1 \mathrm{ml}$, maintained in metal box to prevent being broken during transportation. The bacteria containers must be sterilized at $170 \pm 10^{\circ} \mathrm{C}$ in 2 hours. (APHA 2012)

Table 3. Analytical methods and references of seven parameters for water quality evaluation covered physical, chemical, and biological aspects

\begin{tabular}{|c|c|c|}
\hline Parameters & Analytical methods & References \\
\hline $\begin{array}{l}\text { Free residual Chlorine } \\
\text { Physical characteristic }\end{array}$ & DPD Colorimetric Method & APHA,AWWA,WEF 4500-CL G. \\
\hline Appearance color & Visual Comparison Method & APHA,AWWA,WEF $2120 \mathrm{~B}$. \\
\hline Turbidity & Nephelometric Method & APHA,AWWA,WEF $2130 \mathrm{~B}$. \\
\hline Conductivity & Electrical Conductivity Method & APHA,AWWA,WEF 2510 B. \\
\hline $\begin{array}{l}\mathrm{pH} \\
\text { Chemical characteristic }\end{array}$ & Electrometric Method & APHA,AWWA, WEF 4500- ${ }^{+}$B. \\
\hline $\begin{array}{l}\text { Total Dissolved Solids } \\
\text { (TDS) }\end{array}$ & $\begin{array}{l}\text { Total Dissolved Solids Dried at } \\
180^{\circ} \mathrm{C}\end{array}$ & $\begin{array}{l}\text { In house method based on } \\
\text { APHA,AWWA, WEF } 2540 \text { C. }\end{array}$ \\
\hline $\begin{array}{l}\text { Biological characteristic } \\
\text { Escherichia coli } \\
\text { (E.coli) }\end{array}$ & Fluorogenic Substrate Test & APHA,AWWA,WEF $9221 \mathrm{~F}$. \\
\hline
\end{tabular}

Note; APHA = American Public Health Association, WEF = Water Environment Federation, AWWA $=$ American Water Works Association

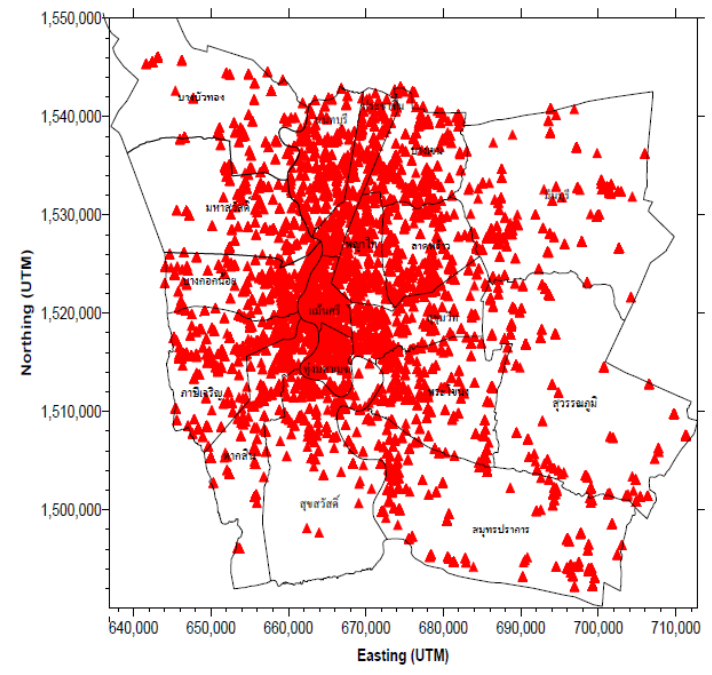

Fig.3 Observation data map of water sampling points during October 2011 to September 2016 


\section{FINDINGS AND DISSCUSSTION}

The samples from participating were collected during October 2011 to September 2016, MWA analyzed 32,711 samples. Seven parameters according to MWA water quality standard (MWA Standard 2013) were implemented for analysis, some of which were reported in this paper as shown in Fig.4. The results showed that tap water, filtered water, filtered dispenser water, and storage water were clear appearance and low turbidity. Their appearance colors were less than 15 TCU. Average turbidity was in the range of 0.17 to 23.4 NTU, the lowest turbidity of which was from filtered water because it had filter for removing particles. Average conductivity ranged from 2 to $3700 \mu \mathrm{S} / \mathrm{cm}$. The high conductivity was from contaminated tap water and filter water. In case of tap water, that is probably because the effect of seawater intruded during drought season, resulting from conventional water technology. In case of filter water, that it feasible because filters did not clan wash. Average total dissolved solids (TDS) tended to be same way of conductivity in the range of 1 to $2220 \mathrm{mg} / \mathrm{l}$ possibly due to the mineral in the water. Average $\mathrm{pH}$ values in the range of 5.80 to 10.55. Their free residual chlorine values were in the range of 0.00 to $2.00 \mathrm{mg} / \mathrm{l}$. The highest free residual chlorine values were from tap water. However, the others were lower free residual chlorine values than the one probably resulting from loss of chlorine during stored in storage tanks or trapped in the filters. Moreover, the results indicate that four types of water were not difference in statistical significance at 0.95 -confidence level, as shown in Table 4.

Table 4. Water quality of water tap water, filtered water, filtered water dispenser, and storage water

\begin{tabular}{lccccccccccccc}
\hline \multirow{2}{*}{ Parameters } & \multicolumn{3}{c}{ Tap water } & \multicolumn{4}{c}{ filtered water } & \multicolumn{3}{c}{$\begin{array}{c}\text { Filtered water } \\
\text { dispenser }\end{array}$} & \multicolumn{3}{c}{ Storage water } \\
\cline { 2 - 14 } & max & $\min$ & P 95 & $\max$ & $\min$ & P 95 & $\max$ & $\min$ & P 95 & $\max$ & $\min$ & P 95 \\
\hline Free residual & 2.00 & 0.00 & 1.06 & 1.13 & 0.00 & 0.00 & 1.03 & 0.00 & 0.00 & 1.71 & 0.00 & 0.14 \\
chlorine & 15.5 & 0.23 & 1.13 & 14.0 & 0.17 & 0.77 & 17.8 & 0.20 & 0.67 & 23.4 & 0.24 & 1.15 \\
Turbidity & 10.55 & 6.48 & 7.70 & 9.89 & 5.80 & 7.76 & 9.53 & 5.93 & 7.85 & 10.12 & 6.29 & 7.76 \\
pH & 2374 & 120 & 501 & 2264 & 3 & 502 & 3240 & 2 & 488 & 3700 & 8 & 503 \\
$\begin{array}{l}\text { Conductivity } \\
\text { Total }\end{array}$ & & & & & & & & & & & & \\
$\begin{array}{l}\text { Dissolved } \\
\text { Solid (TDS) }\end{array}$ & 1424 & 72 & 301 & 1358 & 2 & 301 & 1944 & 1 & 293 & 2220 & 5 & 302 \\
\hline
\end{tabular}

Besides, the results revealed that a number of MWA tap water samples from distribution system had the highest number in compliance with WHO guidelines values for drinking water quality 2011 at $98.40 \%$. The filtered water, filtered water dispenser, and storage water were registered at $96.71 \%$, $95.63 \%$, and $90.88 \%$, respectively as shown in Fig. 5. Interestingly, the consequence of this study showed that a number of water samples classified by water type annually met WHO guidelines levels had a tendency to be same results as those classified by water type during fiscal year 2011 to 2016 (October, 2011 - September, 2016). Results were illustrated in Fig. 6 as following. Furthermore, the water quality of all water types tended to increase compliance with WHO guidelines levels. 


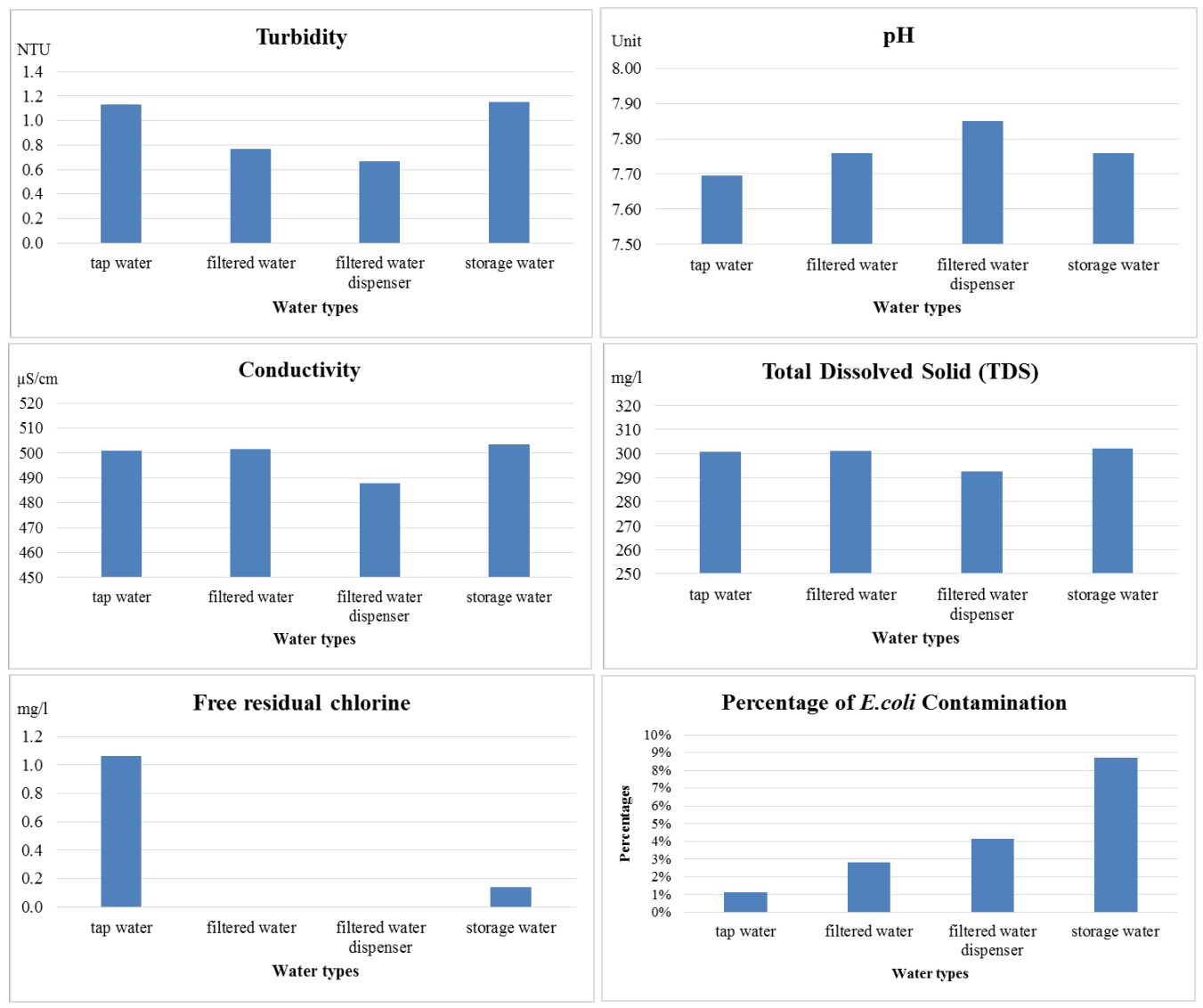

Fig. 4 Average water quality from tap water, filtered water, filtered water dispenser, and storage water classified by parameters

As shown in Fig. 4, the results indicated that the parameters, which were not compliance with WHO guidelines levels, were presence of bacteria E.coli, at $3.78 \%$ of all samples. The $\mathrm{pH}$, turbidity, and TDS gotten above WHO guidelines level were recorded $0.43 \%, 0.28 \%$, and $0.07 \%$, of all samples respectively.

The results showed that the storage water had a highest number of samples, which did not meet WHO guidelines values, at $8.73 \%$. The percentage of $4.13,2.82$, and 1.10 were not compliance with WHO guidelines levels, which were from filtered water dispenser, filtered water, and tap water, respectively. According to free residual chlorine chart (fig. 4), the tap water had higher chlorine values than the others. Therefore, it had a lowest chance to contaminate with bacteria E.coli from various causes such as broken of a storage tank, lack of water equipment maintenance or stain accumulation resulting in E.coli contaminated. WHO recommended in distribution system should be free residual chlorine above $0.2 \mathrm{mg} / 1$ to prevent post contamination. (WHO 2011) Moreover, tap water from distribution systems of MWA were compliance with WHO guidelines values probably because water quality monitoring was frequently monitored as WHO guidelines values both quality and quantity. Besides, MWA has 50 online monitoring stations for surveillance tap water quality. The stations are scattering settled cover our services area. Free residual chlorine, turbidity, 
conductivity, and $\mathrm{pH}$ are shown in online monitoring so that this information is used for immediately water quality management. In addition, chlorination at nine pumping stations is one of the MWA methods to improve tap water quality.

Table 5. WHO guideline values for drinking water quality 2011

\begin{tabular}{llc}
\hline Parameters & Units & $\begin{array}{c}\text { WHO guidelines values for } \\
\text { drinking water quality 2011 }\end{array}$ \\
\hline Free residual Chlorine & $\mathrm{mg} / \mathrm{l}$ & - \\
Appearance color & True Color Unit (TCU) & Less than 15 \\
Turbidity & Nephelo Turbidity Unit (NTU) & 4.0 \\
Conductivity & $\mu \mathrm{S} / \mathrm{cm}$ & - \\
$\mathrm{pH}$ & - & $6.5-8.5$ \\
Total Dissolved Solid (TDS) & $\mathrm{mg} / 1$ & 1000 \\
Escherichia coli $($ E.coli) & $\mathrm{P}-\mathrm{A} / 100 \mathrm{ml}$ & Absence \\
\hline
\end{tabular}

However, MWA tap water from distribution system compliance with WHO guidelines values is safety used and drunk. At present, many houses have storages tank for reserving water and solving low water pressure problem. People do not direct use water supply from distribution pipes so they water used is storage water. Filtered water and filtered water dispenser are used for drink because they need remove chlorine odor and reduce particles in the storage tanks. Nevertheless, the storage tanks and filter are a lot benefits. If they do not take care of equipment, they will make problems. For example, sediment in a bottom tank is collected when it does not clean or expiration filter results in biological contaminated and odor occurred. Therefore, taking care tanks and involved equipment have an effect on water quality.

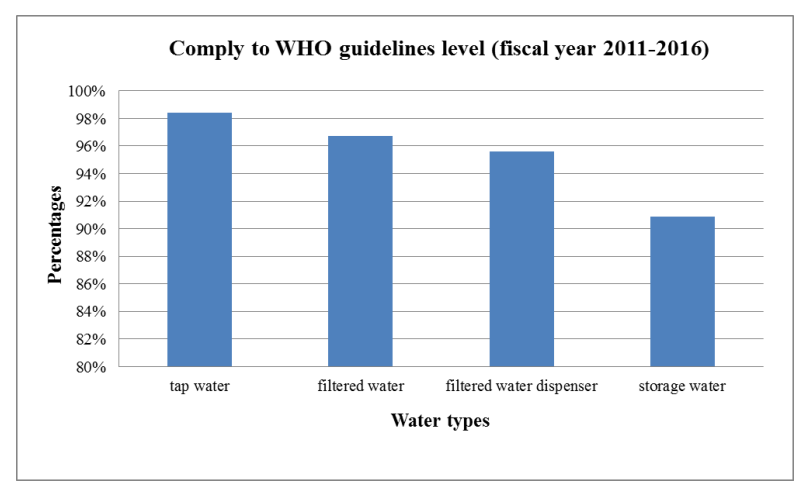

Fig. 5 The percentage of numbers of water sample compliances with WHO guideline values for drinking water quality 2011 classified by water type during fiscal year 2011 to 2016 (October, 2011 - September, 2016) 

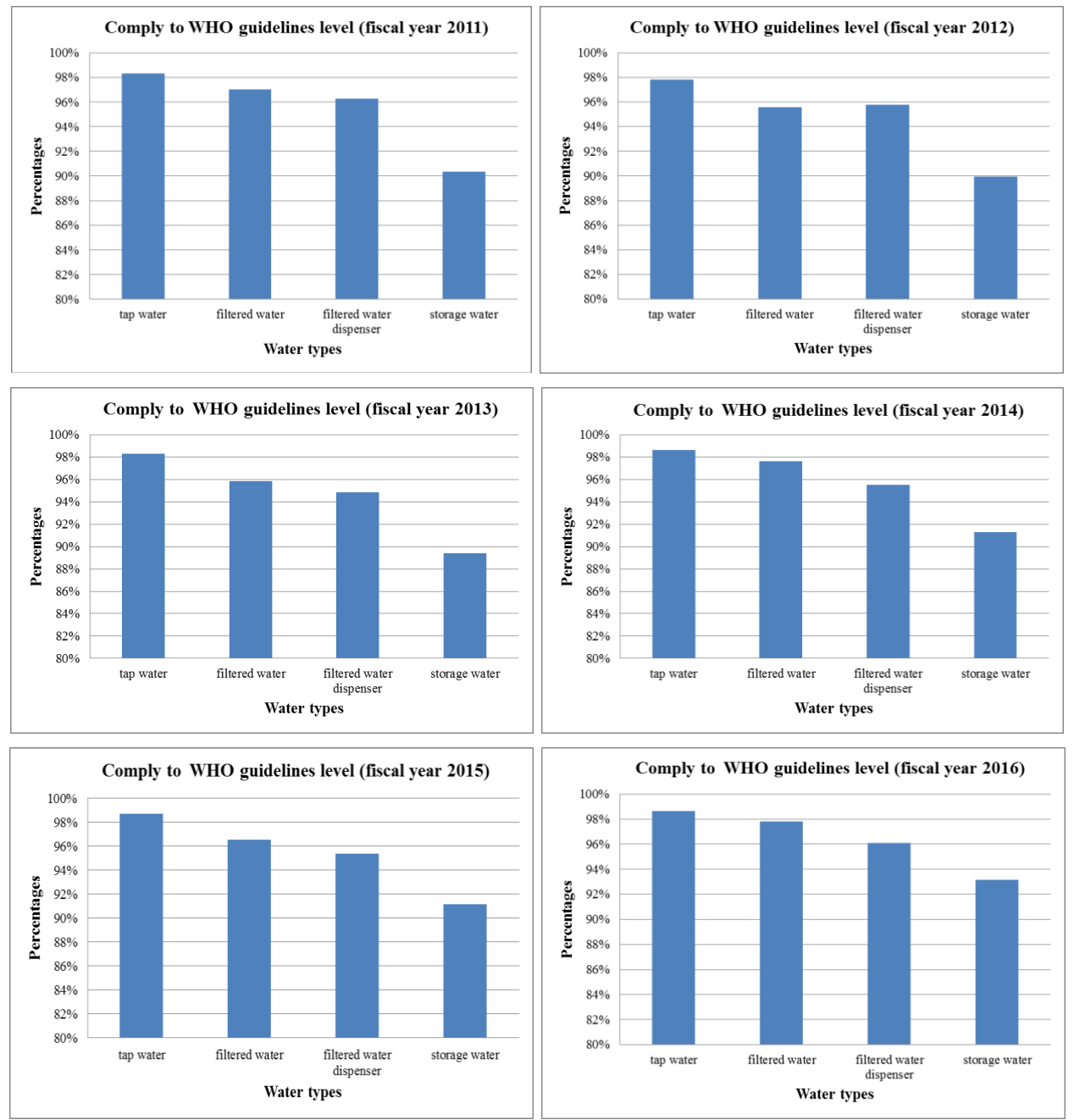

Fig.6 The percentage of numbers of water sample compliances with WHO guidelines values for drinking water quality 2011 classified by water type annually

\section{CONCLUSIONS AND RECOMMENDATIONS}

Consequence of this study, several samples were determined and complied with WHO guidelines for drinking water quality 2011. Tap water quality from pipelines in distribution system were not difference water quality from filter water, filtered water dispenser, and storage water. A number of tap water samples from those were a little many number samples complied with WHO level than any other samples. This is because MWA realized the importance of water quality and determined to improve water quality in the future. In order to build the trust of water supply as drinkable tap water, MWA has created Water Quality Integrated Center. The Water Quality Integrated Center was a hub of water quality management and control of remote automatic chlorination at pumping station. This systems will also increase an adequate amount of free residual chlorine in pipelines to prevent post contamination in faraway from water treatment plants. Moreover, MWA had sent water quality report of attended places to our customers by mail addresses. Customers could access 
water quality information with themselves on the website http://twqonline.mwa.co.th, Facebook clean water clinic, or MWA on mobile application. The dissemination water quality information of tap water to customers would increase trustworthy of water supply and realize that the tap water gained international standard. Customers reached safe use and drink. However, using storage tanks, filter tanks, or filter dispensers should attend to always clean tanks and related equipment or change expired filter to eliminate bacteria contamination risk for safety water.

\section{ACKNOWLEDGEMENT}

The authors are grateful to Metropolitan Waterworks Authority of Thailand for financially supporting for the project and permission to publish these results. We also thank Water Quality Analysis Division for analyzing water samples. Helpful proof reading from Asst. Prof. Dr. Bhakaporn Kuljirundhorn and Ms. Suchayada Mahavana are gratefully acknowledged. Also, we would like to acknowledge the Director of Water Quality Department for their useful suggestion and supporting.

\section{REFERENCES}

Duangta K., Chatchai C., Sopa C. (2013) Confidence of Tap Water for Drinking Purpose in Bangkok Metropolitan and Its Vicinity after Flooding Crisis. Proceeding International Conference on Environmental and Hazardous Substance Management (EHSM 2013). Bangkok. Thailand. O-J08, $1-8$

Kornprabha K., Frank S., Andreas W., Jutta M., and Thomas P. K. (2005). Chemical water quality in Thailand and its impacts on the drinking water production in Thailand. Science of the Total Environment. 340, 57-70

Marie Elize Z.S., Rosangela G.S., Marcio G., Iven C.F., Eliana H.E., Tania U.N., Celso V.N., and Benedito Prado P.D.F. (2008). Int. J. Hyg. Environ. Health. 211, 504-509

Metropolitan Waterworks Authority (MWA): Annual Report 2016 Metropolitan Waterworks Authority. https://www.mwa.co.th/download/pln0201/annual2016/Annual_Report_2016_Eng.pdf (accessed 15 May 2017)

Metropolitan Waterworks Authority (MWA): Metropolitan Waterworks Authority Standard. (In Thai). https://www.mwa.co.th/download/prd01/tws/who2011.pdf (accessed April 2017)

Rosa C., Franco F., and Paolo T. (2011). Drinking water quality: Comparing inorganic components in bottled water and Italian tap water. Journal of Food Composition and Analysis. 24, 184-193

Standard Methods for the Examination of Water and Wastewater (2012). 22nd edn, American Public Health Association, Washington DC, USA. Part 9060 A.2

Standard Methods for the Examination of Water and Wastewater (2012). 22nd edn, American Public Health Association, Washington DC, USA. Part 9060 B.

World Health Organization (WHO) 2011. Guidelines for Drinking Water Quality, 4rd ed, Geneva 